\title{
Genitourinary System Cancer TNM Finding v6
}

National Cancer Institute

\section{Source}

National Cancer Institute. Genitourinary System Cancer TNM Finding v6. NCI Thesaurus.

Code 664405.

A finding about one or more characteristics of genitourinary system cancer, following the rules of the TNM AJCC v6 classification system. 